http://dx.doi.org/10.6113/TKPE.2012.17.6.532

\title{
$\mathrm{HEV}$ 용 고출력 리튬 폴리머 배터리(LIPB)의 수학적 모델링 기법 연구
}

서동우 ${ }^{1}$, 구자경 $^{1}$, 김일송 $^{\dagger}$

\section{A Study on the Mathematical Modeling Techniques for HEV High-power Lithium-Polymer Battery}

\author{
Dong-Woo Seo ${ }^{1}$, Ja-Kyeong $\mathrm{Koo}^{1}$, and $\mathrm{Il}^{-}$Song-Kim ${ }^{\dagger}$
}

\begin{abstract}
This paper proposes the Mathematical Modeling for HEV High-power Lithium-Polymer Battery. The nonlinear system of the Lithium Battery electrical characteristic express mathematical state equation. We also test charge/discharge and temperature experimental used to identify parameters of the cell find parameter of the least error. The proposed model experimental results is used with battery cycler to verify of the proposed model.
\end{abstract}

Keywords: lithium-polymer battery, modeling, HEV

\section{1. 서 론}

$\mathrm{HEV}$ 용 전기 자동차의 리튬 폴리머 배터리 $(\mathrm{Li}-\mathrm{PB})$ 는 적은용량(6.5Ah)에 대전류(200A이상) 충방전이 가능한 배터리로서, 순간적으로 고출력을 낼 수 있는 특징이 있 다.

$\mathrm{HEV}$ 에서 배터리를 운용하기 위한 배터리의 충전량 (SOC) 예측과 유효 출력의 예측은 배터리 관리시스템 $(\mathrm{BMS})$ 의 가장 중요한 기능 중의 하나이다. $\mathrm{SOC}$ 예측을 하기 위해서는 고출력 배터리의 충방전 특성이 다르게 나타나는 전기화학적인 특징을 알아야 한다. 또한, 배터 리의 비선형적인 특성으로 인하여 정교한 모델링으로 나타내는 것 역시 매우 어려운 작업이다.

$\mathrm{HEV}$ 용 배터리 $\mathrm{SOC}$ 추정을 위해 가장 많이 사용되 는 방법 중의 하나인 상태관측기와 칼만 필터(Kalman filter) 기법이 있는데, 이들은 모두 모델 파라미터에 의 해 오차 한계가 결정되기 때문에 정확한 모델 파라미터 를 얻어내는 것이 정교한 $\mathrm{SOC}$ 추정을 위한 가장 중요 한 요소이다. $\mathrm{SOC}$ 추정을 위한 배터리 모델의 파라미터 를 알아내는 배터리 모델링은 배터리의 가동, 상태, 수

Paper number: TKPE-2012-17-6-9 ISSN: 1229-2214

† Corresponding author: iskim@ut.ac.kr, Dept. of Electrical Eng. Korea Nat'l Univ. of Transportation

Tel: +82-43-841-5142 Fax: +82-43-841-5140

${ }^{1}$ Dept. of Electrical Eng. Korea Nat'l Univ. of Transportation Manuscript received Aug. 17, 2012; accepted Oct. 23, 2012
명 등을 예측하는데 가장 필요한 부분이다.

따라서 본 논문에서는 비선형적인 시스템인 셀 데이 터를 이용하여 모델 파라미터와 상태변수를 사용한 수 학적인 모델링으로 나타내고자 한다.

현재 리튬배터리에 대한 모델링 기법이 활발히 연구 되고 있으며 몇 가지를 살펴보면, 배터리 내부의 임피던 스를 측정하고 그에 따른 동특성 모델링을 할 수 있는 전기화학적 임피던스 분광법 EIS(Electrochemical Impedance Spectroscopy) $)^{[1]}$ 는 RLC소자를 이용한 등가 회로를 이용하여 정확한 배터리의 비선형적인 동작특성 을 나타 낼 수 있지만 과도상태 및 $\mathrm{DC}$ 응답이 제한된다.

내부저항과 배터리 내부의 전기화학적인 반응에 의한 비선형적인 특성을 나타내는 저항과 커패시턴스로 등가 회로를 만든 테브낭(Thevenin Model) 배터리 모델링 기 법은 ${ }^{[2]}$ 저항과 커패시턴스로 구성된 파라미터가 $\mathrm{SOC}$ 추 정에 사용되지만 상수로만 표현되는 단점이 있다.

배터리의 충-방전 전류를 적분하여 현재 충전상태를 계산하는 쿨롱카운팅(Coulomb Counting Method) 기법 은 ${ }^{[3]}$ 측정이 쉽고 정확하지만 전기자동차나 하이브리드 자동차와 같은 순간적인 충 - 방전이 일어나는 동적시스 템에는 오차가 많기 때문에 적합하지 못하다.

또한, 개방회로전압(Open Circuit Voltage) 기법이 있 는데 배터리의 $\mathrm{OCV}$ 를 측정하기 위해서는 배터리에 전 류를 인가한 뒤에 휴식기를 거쳐 안정화 상태가 된 후 에 전압을 측정해야 하므로 실시간 측정이 불가능하기 때문에 순간적인 전류 특성이 있는 $\mathrm{HEV}$ 용 배터리 모델 
링 기법에는 맞지 않다. OCV기법은 ${ }^{[4]}$ 다른 $\mathrm{SOC}$ 추정기 법과 함께 결합되어 사용한다.

본 연구에서는 $\mathrm{HEV}$ 용 고출력 대용량 배터리를 이용 하여 배터리의 전기화학적인 특성을 상태방정식 형태로 나타낸 수학적 모델링 기법을 제시한다. ${ }^{[5][6]}$ 이 수학적인 모델링을 통해 모든 종류의 셀에 대응 가능한 배터리 모델링 기법을 구축할 수 있게 한다.

배터리의 $\mathrm{OCV}$ 특성과 Hysteresis, Polarization 현상 적용을 하여 상태방정식을 수립하고 수학적 모델링의 파라미터를 알아내 배터리 모델링의 선형화를 한다.

실험 측정은 $5 \mathrm{~V} / 100 \mathrm{~A}$ 급 대용량 충방전 장치 및 온도 챔버를 사용하여 직접 데이터를 측정하고, 측정된 데이 터와 제안된 파라미터 추출 기법을 통해 제시된 모델링 의 성능을 검증하였다.

\section{2. 본 론}

\section{1 배터리 변수 정의}

배터리 모델링을 하기 위해 다음과 같이 모델링에 필 요한 변수 정의를 한다.

\subsection{1 배터리의 개방전압}

충방전이 없는 안정화 상태에서의 배터리는 개방회로 전압으로 나타낼 수 있고 비선형 함수로 나타낸다.

$\mathrm{OCV}$ 데이터는 만충전 전압 $(4.2 \mathrm{~V})$ 에서 컷오프 전압 $(2.7 \mathrm{~V})$ 에 도달하기 전까지 $0.1 \mathrm{C}$ 로 방전하고 20 단계의 $\mathrm{OCV}$ 데이터를 얻어낸다. 이 과정은 셀의 SOC를 $100 \%$ 에서 $5 \%$ 씩 감소시키면서 얻어내는 데이터 방법이다.

그림 1은 실험에 사용된 고출력 배터리(6.5Ah)의 2 $5^{\circ} \mathrm{C}$ 에서 $\mathrm{SOC}$ 대비 $\mathrm{OCV}$ 의 관계를 나타낸 것이다.

\subsubsection{SOC의 정의}

$\mathrm{SOC}$ 는 셀의 공칭용량 대비 남아 있는 용량으로 정 의 되며, 잔존 용량은 상온에서 $\mathrm{C} / 30$ 비율로 셀에서 방 전 가능한 $\mathrm{Ah}$ 값이다. $\mathrm{SOC}$ 의 관계식은 다음과 같다.

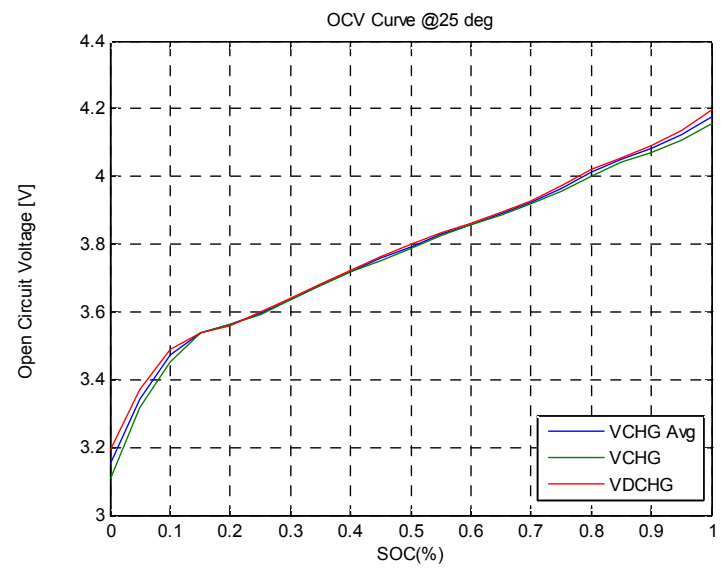

Fig. 1 25deg OCV-SOC Curve

$$
z(t)=z(0)+\int_{0}^{t} \frac{i(\tau)}{C_{n}} d \tau
$$

$z(t)$ 는 셀 $\mathrm{SOC}$ 이고, $C_{n}$ 은 셀의 공칭용량이다. $i(\tau)$ 는 충방전 전류를 나타낸다.

\subsection{3 분극현상}

분극현상(Polarization effect)은 충방전시에 발생하는 전해액의 농도차가 확산에 의해 균일화 되는 과정으로 생각할 수 있다.

본 논문에서 $V_{p 1}$ 은 Short term polarization effect, $V_{p 2}$ 는 Long term polarization effect로 나타내었다. Short term polarization effect는 충방전 기간 동안과 종 료 후 1 분에서 10 분 이내에 나타나는 전압 현상을 말하 며, Long term polarization effect는 충방전 종료 후 10 분에서 1 시간 동안에 나타나는 전압 현상이며, 그림 2 와 같이 나타낼 수 있다.

\subsection{4 히스테리시스 현상}

배터리 단자 전압의 동일 충전량 $(\mathrm{SOC})$ 에서 충전과 방전이 다르게 나오는 것을 히스테리시스 현상 (Hysteresis effect)이라고 한다. 그림 3은 실험에 사용된 고출력 배터리(6.5Ah)의 충전과 방전 $\mathrm{SOC}$ 범위 안에서 의 히스테리시스 현상을 나타낸다.

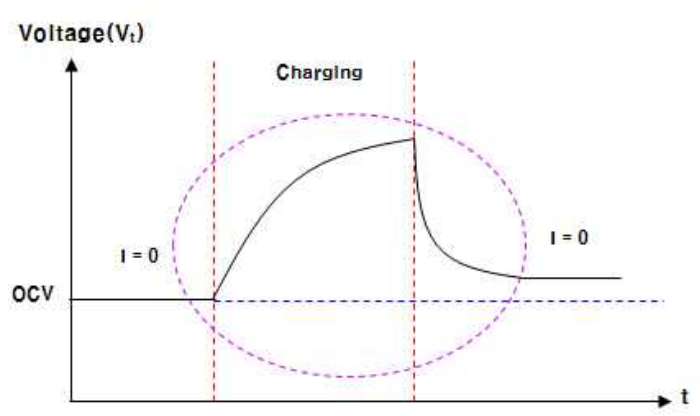

Fig. 2 Polarization effect due to the charge/discharge current

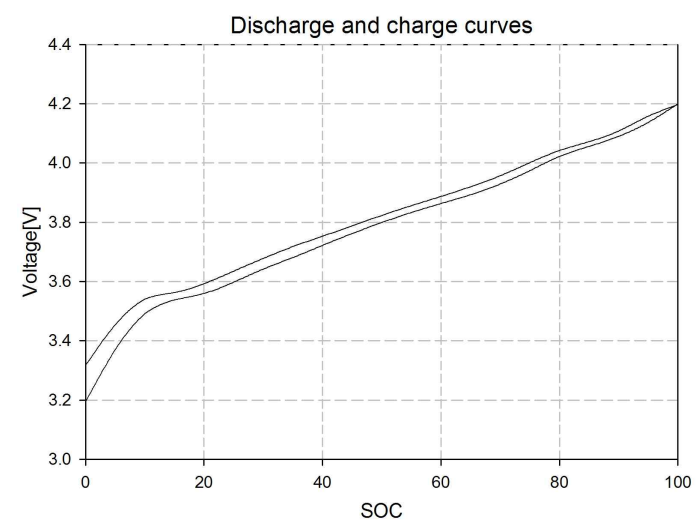

Fig. 3 Discharge and charge curves illustrating hysteresis 


\subsection{5 배터리 모델링}

배터리의 전기화학적인 특성을 전기회로나 상태방정 식으로 표현하게 된다. 이는 배터리의 상태(state), 수명 (health)등을 예측하는데 가장 필요한 부분이다.

배터리의 전기적 동적 특성을 다음의 그림 4 와 같이 나타낼 수 있으며 배터리의 단자 전압 방정식은 식 (2) 과 같이 주어진다.

$$
V_{\text {bat }}=V_{\text {oc }}+R i_{k}+V_{p 1}+V_{p 2}+V_{h}
$$

$V_{o c v}$ 는 충전량(SOC)으로 이루어진 비선형 전압원이 고, $V_{p 1}$ 과 $V_{p 2}$ 는 분극 현상을 나타내는 커패시턴스와 충방전 전류로 인한 손실저항으로 이루어져 있다. $R$ 은 내부저항을 나타내고, $V_{h}$ 는 전지의 Hysteresis 전압을 나타낸다. Hysteresis 전압은 동일 충전량(SOC)에서 충 전과 방전시 다르게 나오며 전압 차이는 비례하지 않고 충전량에 따라 달라진다. 충방전 전류는 $i_{k}$ 로 나타내며 충전시 $(+)$, 방전시 $(-)$ 의 값을 가진다.

\section{2 수학적 모델링}

실험을 통하여 얻어진 데이터로 전지의 개방전압과 히스테리시스 현상을 적용하여 상태 방정식을 수립할 수 있다. 또한 수학적 모델링에 필요한 셀 모델의 파라 미터를 추출하며, 파라미터는 최소자승법을 이용하여 추 정하였다. 셀 모델의 파라미터 추출을 위해 배터리 모델 링인 Enhanced Self-Correcting(ESC) Model ${ }^{[5][6]}$ 을 사용 한다.

최적파라미터를 추출하기 위해 충방전 데이터들을 이 용한 최소자승법을 사용하였으며 최소자승법의 식은 다 음과 같다. ${ }^{[8]}$

$$
\begin{aligned}
& Y=\left[y_{1}-O C V\left(z_{1}\right)-G f_{1}, y_{2}-O C V\left(z_{2}\right)\right. \\
& \left.-G f_{2}, \ldots, y_{n}-O C V\left(z_{n}\right)-G f_{n}\right]^{T} \\
& H=\left[h_{1}, h_{2}, \ldots, h_{n}\right]^{T} \\
& h_{j}^{T}=\left[i_{j}^{+}, i_{j}^{-}, z_{j}, h_{j}\right] \\
& Y=H \theta, \theta^{T}=\left[R^{+}, R^{-}, M, \gamma\right]
\end{aligned}
$$

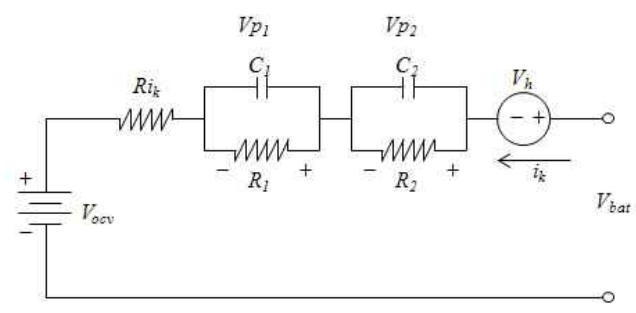

Fig. 4 LIPB Battery dynamic model structure

$$
\theta=\left(H^{T} H\right)^{-1} H^{T} Y=H / Y
$$

$H, Y:$ Known matrices, $n=32,000$ data set

여기에서 $Y$ 는 출력벡터, $H$ 는 시스템행렬, $\theta$ 는 파라 미터 벡터, $R$ 은 충방전 저항, $M$ 은 히스테리시스 전압, $\gamma$ 는 히스테리시스 반응속도상수이다.

\subsubsection{Enhanced Self-Correcting(ESC) Model}

UDDS(Urban dynamometer driving schedule) 프로파 일을 통해 셀 파라미터를 변화값을 알아내는 것이 제일 중요하며 Enhanced Self-Correcting(ESC) 모델링 방법 으로 최소의 오차를 가지는 파라미터를 알아낸다. ${ }^{[6][7]}$ 제 안된 모델링은 배터리 충방전에 발생하는 전류를 입력 으로 하는 저역통과(low-pass filter)로 구현이 가능하다.

출력방정식은 다음과 같은 식으로 나타낼 수 있다. 충 방전을 통해 얻은 $\mathrm{OCV}$ 데이터와 배터리 내부저항, 분극 화를 나타내는 손실저항, 이중층의 커패시턴스를 포함한 다.

$$
y_{k}=O C V\left(z_{k}\right)+h_{k}+f i l t\left(i_{k}\right)-R i_{k}
$$

이 수식에서 필터 $\operatorname{filt}\left(i_{k}\right)$ 의 기능은 rest period 후에 $y_{k}$ 가 $O C V$ 로 수렴하도록 하고, 일정 전류로 충방전할 때 $y_{k}$ 가 $O C V+h_{k}-R i_{k}$ 로 수렴하도록 한다.

선형필터 $f i l t\left(i_{k}\right)$ 을 상태 공간 방정식으로 나타내면 다음과 같다.

$$
\begin{aligned}
& f_{k+1}=A_{f} f_{k}+B_{f} i_{k} \\
& y_{k}^{f}=G f_{k}
\end{aligned}
$$

$F\left(i_{k}\right)$ 는 다음과 같이 정의 한다.

$$
F\left(i_{k}\right)=\exp \left(-\left|\frac{\eta_{i} \cdot i_{k} \cdot \Delta t}{C_{n}}\right|\right)
$$

최종 상태 공간 방정식으로 나타낸 $\mathrm{ESC}$ Model은 다 음과 같다.

$$
\left[\begin{array}{l}
f_{k+1} \\
h_{k+1} \\
z_{k+1}
\end{array}\right]=\left[\begin{array}{ccc}
\operatorname{diag}(\alpha) & 0 & 0 \\
0 & F\left(i_{k}\right) & 0 \\
0 & 0 & 1
\end{array}\right]\left[\begin{array}{l}
f_{k} \\
h_{k} \\
z_{k}
\end{array}\right]+\left[\begin{array}{cc}
B_{f} & 0 \\
0 & 1-F\left(i_{k}\right) \\
-\frac{\eta_{i} \cdot \Delta t}{C_{n}} & 0
\end{array}\right]\left[\begin{array}{c}
i_{k} \\
\operatorname{sgn}\left(i_{k}\right)
\end{array}\right]
$$

$\alpha$ 는 선형 필터의 극점들을 의미한다.

$$
\begin{aligned}
\operatorname{sgn}\left(i_{k}\right) & =1, i_{k}>0 \\
& -1, i_{k}<0
\end{aligned}
$$


출력 $y_{k}$ 는 다음과 같다.

$$
y_{k}=O C V\left(z_{k}\right)-R i_{k}+M h_{k}+G f_{k}
$$

\subsubsection{UDDS 주행 프로파일}

$\mathrm{HEV}$ 용 자동차의 셀 모델 파라미터를 추출하기 위해 실 주행 파라미터가 필요하며 실 주행 조건에서 정속주 행 구간은 정확한 파라미터를 얻기 쉬우나, 잦은 가감속 구간에서는 파라미터의 변화가 심하여 오차가 커진다.

따라서 파라미터를 얻기 위해 실 주행 조건과 비슷한 잦은 가감속을 연속으로 가한 테스트 프로파일을 적용 하는데, 그 중 하나인 UDDS(Urban dynamometer driving schedule) 프로파일을 기준으로 적용하였다. $\mathrm{UDDS}$ 는 주기적인 펄스 방전시험으로서 셀 파라미터를 추출하는데 이용된다.

본 논문에서 사용된 UDDS의 주기는 1 cycle 동안 1800 초로 구성되어 있으며 초기 180초 동안 $50 \mathrm{~A}$ 방전, 5 분 휴식 후 충방전을 시작한다. 전체 주기는 $13 \mathrm{cycle}$ 로서 총 $6.38 \mathrm{Ah}$ 방전을 하는 프로파일이다. 그림 5 와 같이 나 타내며 본 논문의 실험에 적용한 UDDS 프로파일이다.

\subsection{3 실험}

실험은 $5 \mathrm{~V} / 100 \mathrm{~A}$ 충방전기를 이용하여 선정된 $\mathrm{A}$ 사의 $\mathrm{HEV}$ 용 $6.5 \mathrm{Ah}$ 셀을 상온 $25^{\circ} \mathrm{C}$ 기준으로 측정 하였다. 셀 모델 파라미터 추출에 필요한 $\mathrm{OCV}$ 데이터와 실 주 행 프로파일인 UDDS 프로파일을 이용하여 만충전 $(4.2 \mathrm{~V})$ 상태에서 컷오프 $(2.7 \mathrm{~V})$ 전압까지 셀 데이터를 얻 어낸다. 얻어낸 셀 데이터를 가지고 분석을 위해 Matlab 을 활용하여 파라미터 계산을 한다.

\section{3 결과 및 분석}

본 논문에서 제안된 방법을 검증하기 위해 1 차 필터 와 2 차 필터, 3 차 필터를 사용하여 $\mathrm{ESC}$ 모델링 방법을 분석하고 검증하였다. 검증을 위해 Matlab을 사용하여 제안된 식의 최적 파라미터 조합을 계산한다.

여기서 1 차 필터의 경우 5 개의 파라미터 조합을 계산
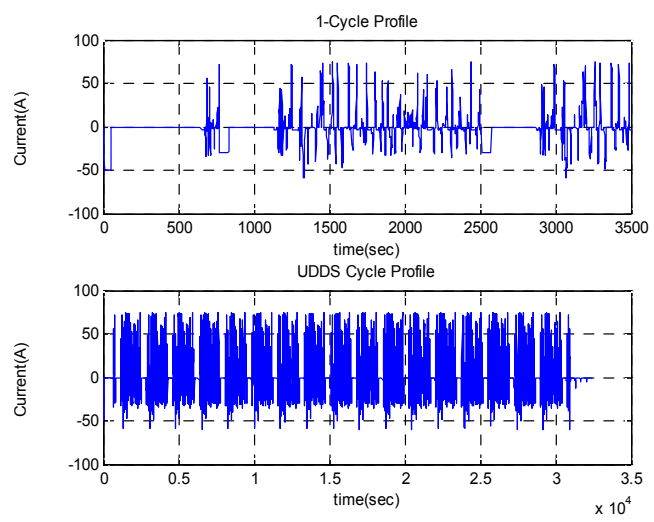

Fig. 5 UDDS Cycle Profile
Table 1 Result of Cell Cost

\begin{tabular}{|c|c|c|c|}
\hline & Filter 1 & Filter 2 & Filter 3 \\
\hline Cost & 0.013761 & 0.006113 & 0.005828 \\
\hline
\end{tabular}

하는 함수이고, 2 차 필터의 경우 7 개의 파라미터 조합을 계산해주는 함수이며, 3 차 필터의 경우 9 개의 파라미터 조합을 계산하는 함수이다. 여기서, 중요한 것은 셀 모 델의 파라미터 오차를 최소화 시키는 조합의 함수를 찾 아내는 것이 관건이다.

Matlab을 활용하여 파라미터를 추출하고 셀 모델의 파라미터 오차를 최소화 시켜 조합을 찾아내는 함수를 찾는다. 필터 차수에 대한 모델 에러 결과 값을 다음과 같이 정의 하며 표 1 과 같이 값을 정리하며 최적 파라 미터의 범위는 $\mathrm{SOC}=10 ~ 90(\%)$ 사이만 적용하였다.

또한 표 1 을 통해 1 차 필터부터 3 차 필터까지의 에러 연산 값 오차를 비교하였을 때 서로의 차이가 0.002 0.007 정도로 크지 않음을 볼 수 있다.

$$
\begin{aligned}
& E=y-\hat{y} \\
& \cos t=\sqrt{\frac{\left(E E^{T}\right)}{n}}
\end{aligned}
$$

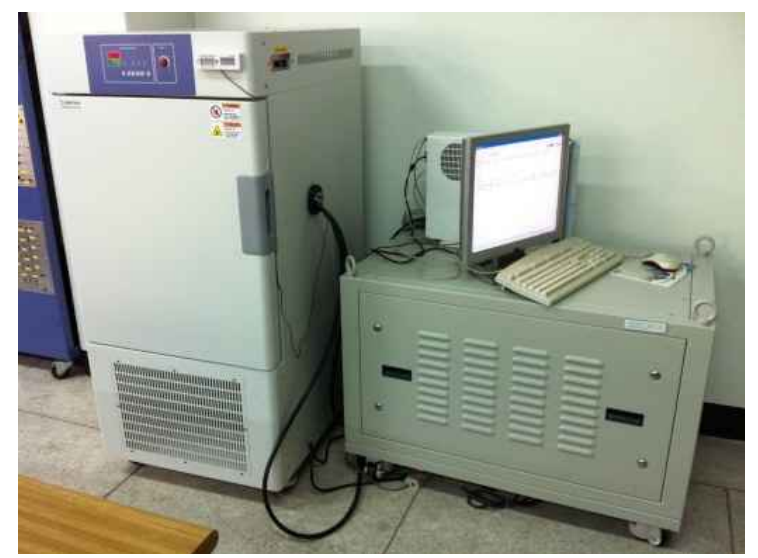

Fig. 6 Temp. Humi. Test Chamber \& 5V 100A Battery Cycler

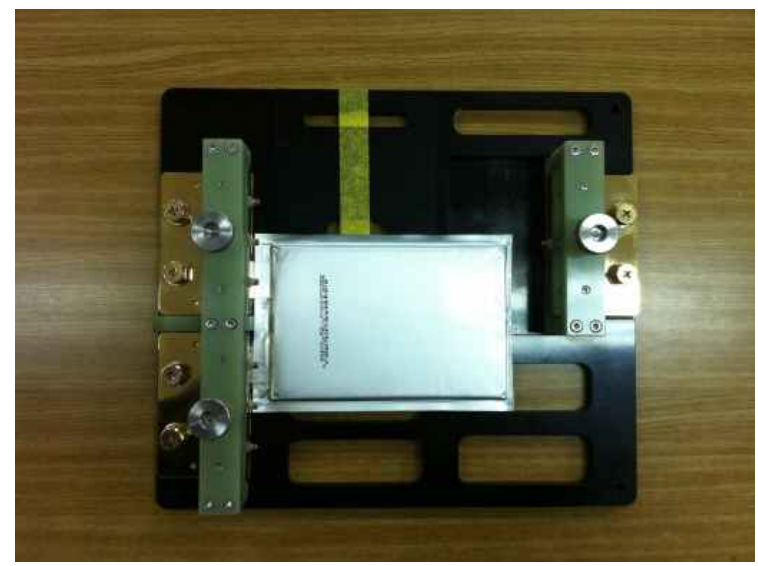

Fig. 7 Li-PB Battery 6.5Ah cell for $\mathrm{HEV}$ 
그림 8 부터 그림 16 까지는 $\mathrm{ESC}$ 모델에서 1 차 필터부 터 3차 필터까지 사용하여 적용한 파라미터 상수에 대 한 모델 오차와 출력 파라미터와의 관계의 결과를 Matlab을 통하여 그래프로 나타내고 있다.

또한 이렇게 필터를 이용한 최적의 파라미터를 구함 으로써 비선형인 값을 선형으로 근사화 할 수 있다.

\section{3. 결 론}

본 논문에서는 $\mathrm{HEV}$ 용 리튬 폴리머 배터리 시스템의 수학적 모델링을 적용하는 방법을 소개하였다. 제안된 시스템의 성능은 고성능 충방전기를 통한 셀의 $\mathrm{OCV}$ 데 이터와 UDDS 프로파일 시험에 의해 입증되었다.
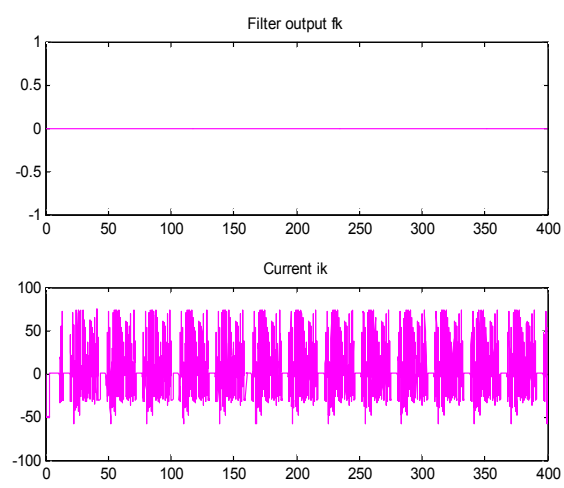

Fig. 8 Result for Filter output $f_{k} \&$ Current $i_{k}$ (Filter state 1)
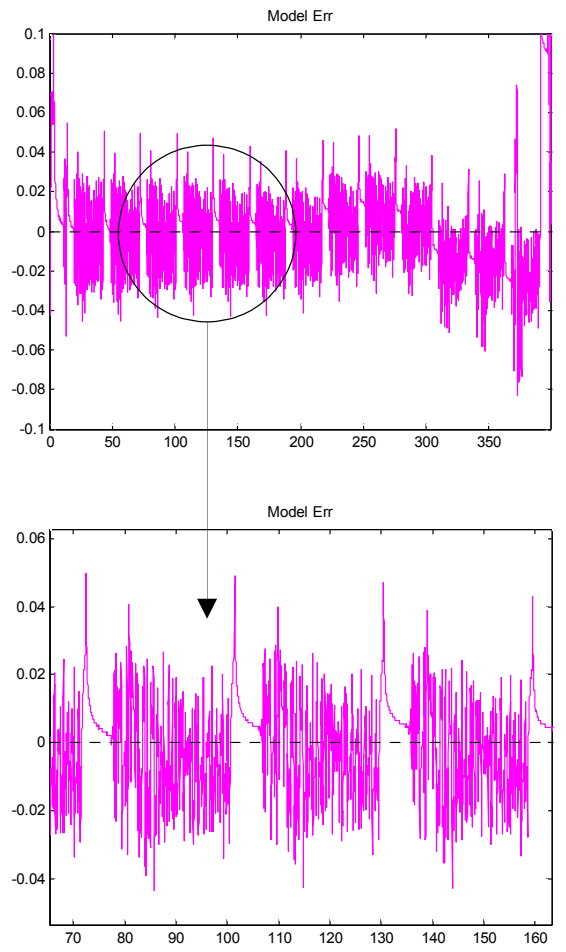

Fig. 9 Result for voltage error of time (Filter state 1)

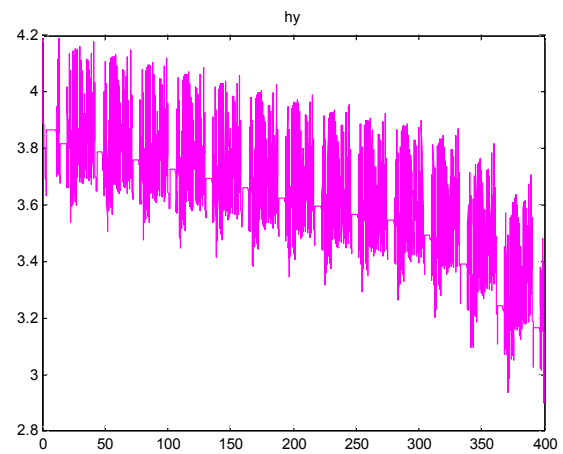

Fig. 10 Result of cell modeling for the UDDS cell test. (Filter state 1)
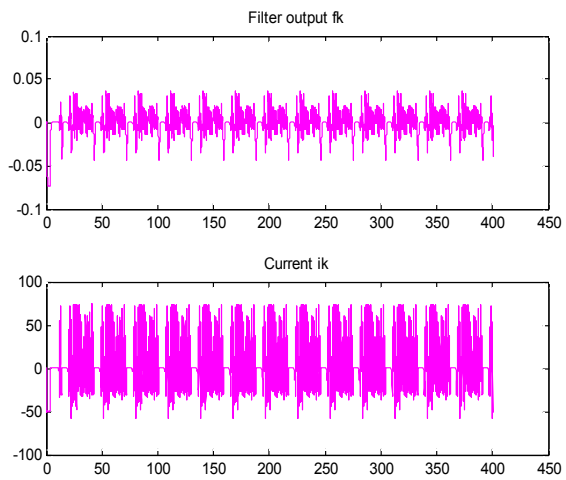

Fig. 11 Result for Filter output $f_{k} \&$ Current $i_{k}$ (Filter state 2)
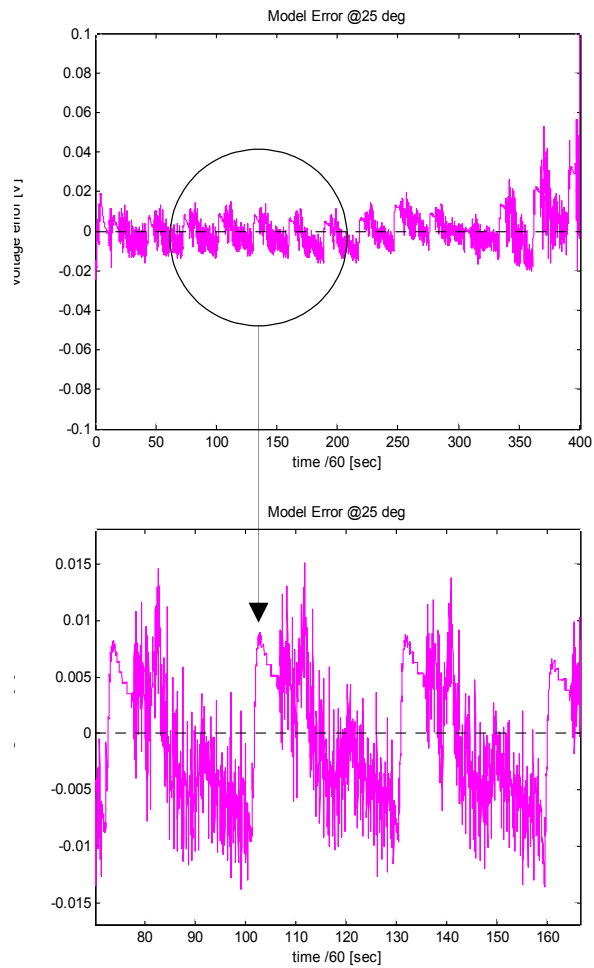

Fig. 12 Result for voltage error of time (Filter state 2) 


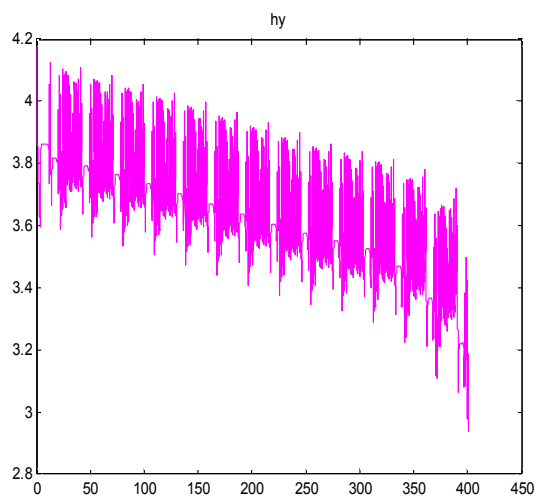

Fig. 13 Result of cell modeling for the UDDS cell test. (Filter state 2)
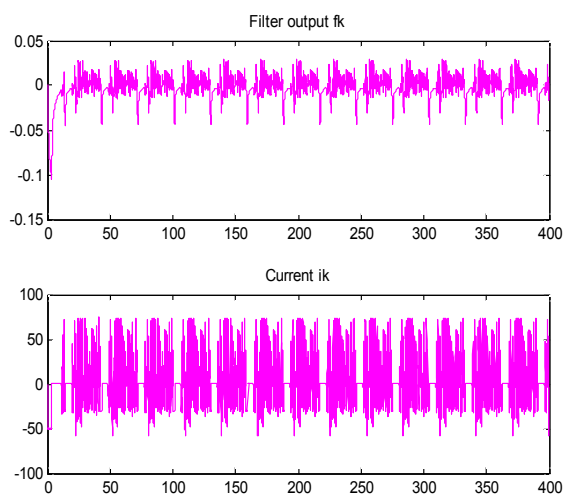

Fig. 14 Result for Filter output $f_{k} \&$ Current $i_{k}$ (Filter state 3)
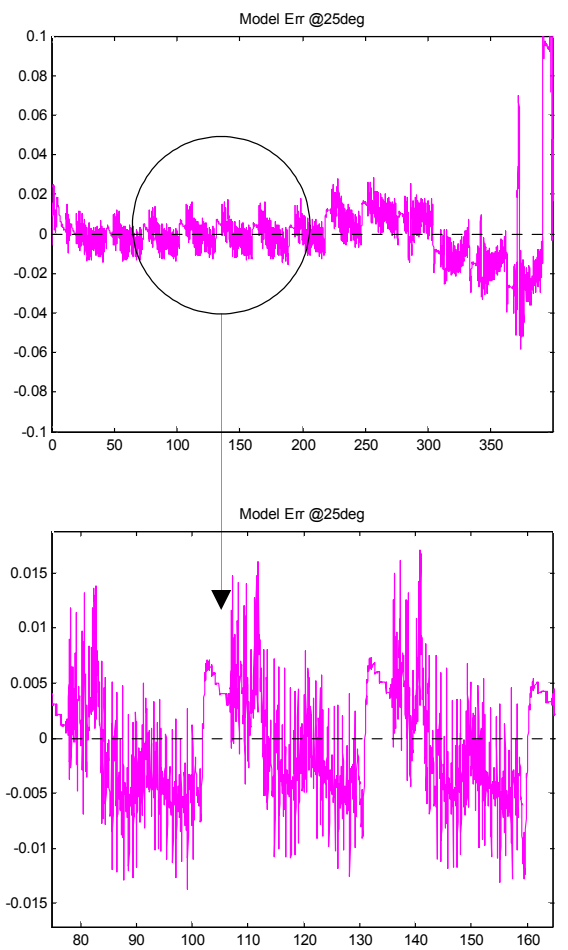

Fig. 15 Result for voltage error of time (Filter state 3)

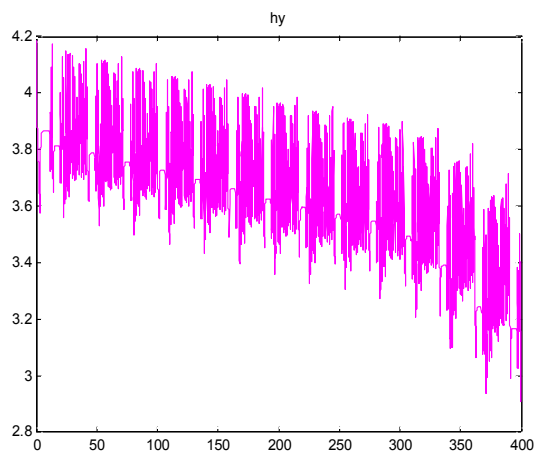

Fig. 16 Result of cell modeling for the UDDS cell test. (Filter state 3)

3차 필터에서 다른 차수의 필터 보다 에러 연산 값이 더 작게 나왔지만 차수가 늘어나는 고차 필터가 될수록 파라미터가 최적의 조합을 찾기 위해 연산에 따른 계산 량이 많아지고 연산 시간이 늘어난다. 이렇게 되면 시스 템의 리소스를 많이 소모하게 되는 단점이 발생한다.

따라서 세 가지의 필터에 대한 오차 크기가 서로 크 지 않은 점을 감안하였을 때, $\mathrm{ESC}$ 모델에서 최적의 필 터는 시스템의 리소스도 적게 차지하면서 오차가 작게 나오는 2 차 필터를 최적의 필터로 적용한다. 추후에 온 도에 따른 파라미터의 변화값에 대한 오차를 최소화하 는 파라미터와 $\mathrm{OCV}$ 의 변화량의 추출을 통해 적합성을 따지는 연구가 필요하다.

본 논문은 2012년도 한국교통대학교 교내학술 연구비의 지원을 받아 수행한 연구입니다.

본 논문은 지식경제부의 재원으로 한국에너지 기술평가원의 지원을 받아 수행한 연구과제입니 다.(과제명 : $10 \mathrm{KWh}$ 급 LIB ESS 가정용 계통연계 형 전력제어시스템 개발 No. G031454511)

\section{참 고 문 헌}

[1] S. Buller, M. Thele, E. Karden, R. W. D. Doncker, "Impedance-based Non-linear Dynamic Battery Modeling for Automotive Applications," Journal of Power Sources, Vol. 113, pp. 422-430, Jan. 2003.

[2] Min Chen, Gabriel A. Rincon-Mora, "Accurate Electrical Battery Model Capable of Predicting Runtime and I_V Performance," IEEE Transaction on Energy Conversion, Vol. 21, No. 2, pp. 504-511, Jun. 2006.

[3] S. Piller, M. Perrin, A. Jossen, "Methods for State-of-charge Determination and Their Applications," Journal of Power Sources, Vol. 96, pp. 113-120, Jun. 2001. 
[4] I. Snihir, W. Rey, E. Verbitsky, A. B. Ayeb, P. H. L. Notten, "Battery Open-Circuit Voltage Estimation by a Method of Statistical Analysis," Journal of Power Sources, Vol. 159, pp. 1484 - 1487, Sep. 2005

[5] Plett, G., "Extended Kalman Filtering for Battery Management Systems of LiPB-Based HEV Battery Packs - Part 1: Background," Journal of Power Sources, Vol. 134, No. 2, pp. 252 - 261, Aug. 2004.

[6] Plett, G., "Extended Kalman Filtering for Battery Management Systems of LiPB-Based HEV Battery Packs-Part 2: Modeling and Identification," Journal of Power Sources, Vol. 134, No. 2, pp. 262-276, Aug. 2004.

[7] Plett, G., "Extended Kalman Filtering for Battery Management Systems of LiPB-Based HEV Battery Packs-Part 3: State and Parameter Estimation," Journal of Power Sources, Vol. 134, No. 2, pp. 277 292, Aug. 2004.

[8] Plett, G., "Recursive approximate weighted total least squares estimation of battery cell total capacity," Journal of Power Sources, Vol. 196, No. 4, pp. 2319 2331, Feb. 2011.

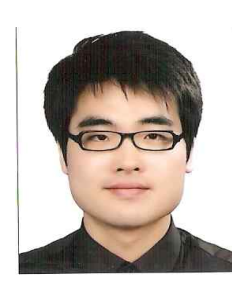

\section{서동우(徐東佑)}

1983년 7월 15일생. 2009년 한국교통대 전 기공학과 졸업. 2011년 현재 동 대학원 전 기공학과 석사과정.

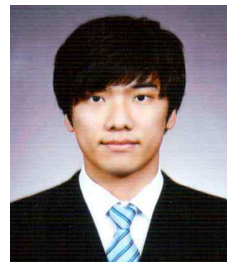

구 자경 (具滋卿)

1986년 11월 25일생. 2012년 한국교통대 전기공학과 졸업. 2012년 현재 동 대학원 전기공학과 석사과정.

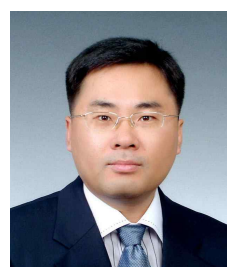

김일 송 (金一松)

1968년 7월 3일생. 1991년 연세대 공대 전 자공학과 졸업. 1994년 한국과학기술원 전 기 및 전자공학과 졸업(석사). 2005년 동 대 학원 졸업(공박). 1994년 1999년 현대전자 위성사업단. 2005년 2007년 LG화학 배터 리 연구소 책임 연구원 현재 한국교통대 전기공학과 부교수. 